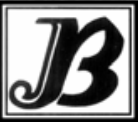

J. bio-sci. 14: 49-55, 2006

ISSN 1023-8654

\title{
STUDY OF BEETLES (COLEOPTERA) ASSOCIATED WITH STORED PRODUCTS OF KOLKATA, INDIA III. FAMILY: STAPHYLINIDAE
}

\author{
P K Basak ${ }^{1}$ and TK Pal ${ }^{2}$ \\ ${ }^{1}$ Department of Zoology, Bidhannagar College, Saltlake, Kolkata-700064, India \\ Email : basak.prabir @ rediffmail.com \\ 2 Zoological Survey of India, M-Block, New Alipore, Kolkata-700053, India \\ Email : tkpal51@ rediffmail.com
}

\begin{abstract}
Six species of Staphylinidae under the genera Philonthus Curtis, Coenonica Kraatz, Aleochara Grouvelle and Oligota Mannerheim are reported from 18 different commodities in Kolkata area. All these species are new to the stored product habitat from India. Their diagnostic features with illustrations, distribution and habitat records are dealt with and an identification key to these species is given.
\end{abstract}

Key words: Coleoptera, Staphylinidae, Systematics, Stored products, Kolkata

\section{Introduction}

Staphylinidae or rove beetles are a family of mostly predaceous beetles, occurring in diverse habitats that can be recognized by their truncate elytra and narrow, slender body forms. Lawrence (1982) mentioned about 30,000 species of Staphylinidae from the world, of which about 3,000 species were known to occur in India (Pal 2003). Cameron (1930, 1931a,b, 1932, 1939a,b) didn't mention any staphylinids from storage products in the Fauna of British India volumes. Aitken (1975) enlisted about 35 species of Staphylinidae from worldwide cargoes of which only Xantholinus glabratus (Gravenhorst) and Tachinus subterraneus (Linnaeus) were within the commodities from India. In the present study, 6 other species belonging to the genera Philonthus Curtis, Coenonica Kraatz, Aleochara Grouvelle and Oligota Mannerheim were intercepted, in course of an intensive survey of stored commodities of Kolkata and its surroundings, during 1982-1985. All these species are new records to the stored product habitats from India. Systematic accounts of these species are given and a key to their identification is incorporated.

\section{SYSTEMATIC ACCOUNT}

Subfamily: STAPHYLININAE

Tribe: Staphylinini

Genus: Philonthus Curtis

Philonthus Curtis 1825 Brit. Ent. 13 : 610

This is a large genus including 145 Indian species (Cameron 1932) occurring mostly in dung and carcasses. These can be recognized by their elongate appearance with shiny head and thorax. Head constricted behind, excerted; antennal pedicel neither dilated nor geniculate; third joint of labial palpi pointed apically; anterior 
tibiae normally dilated, all the tibiae pubescent and impunctuate; superior lateral lines of thorax slightly deflexed with large anterior setiferous punctures.

Aitken (1975) mentioned 11 species of Philonthus Curtis from cargoes of the world, none of which are from India. All three species of this genus, intercepted in the present study, are new records from the stored product habitat of India.

\section{Philonthus paederoides Motschulsky}

Philonthus paederoides Motschulsky 1858. Bull. Mosc. 2: 662.

Diagnosis: Body (Fig. 1) shining, head black, thorax bright red, elytra blue; abdomen red, posterior half of fifth and entire sixth segments black; antenna blackish, segment 10 reddish; legs yellowish-red, tibiae infuscate.

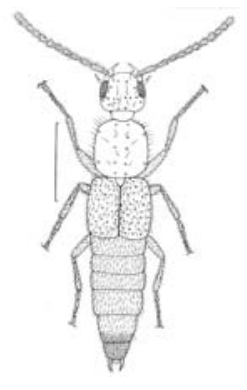

Fig.1. Philonthus paederoides Motschulsky, Dorsal view.

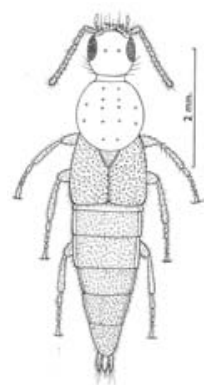

Fig.2 Philonthus minutus Boheman, Dorsal view.

Length: 7.9-8.1mm.

Material studied: 5ex., INDIA: W. Bengal, Howrah, wholesale fish market, 15.i.1982, P K Basak ex. baskets and gunny sacs containing fishes.

Distribution: Indonesia (Sumatra), Philippines, Indo-China, India and Sri Lanka. From India, the species known from Tamil Nadu, Karnataka, Uttar Pradesh and presently from West Bengal: Kolkata.

Remark: No habitat record of this species is available in the existing literature and in the present study these were collected from baskets and gunny sacs used to carry fishes.

Philonthus minutus Boheman

Philonthus minutus Boheman 1848, Ins. Caffr. 1: 279.

Diagnosis: Body (Fig. 2) pisciform, black, shining; elytra pitchy with the suture and apical margin narrowly bordered reddish-yellow, the reflex margin more broadly reddish-yellow; abdomen slightly iridescent; thorax with dorsal row of five punctures; antenna black, apical segment yellow; legs yellow, tibiae infuscate.

Length: $5.5-7.5 \mathrm{~mm}$.

Material studied: 4ex..; INDIA: W. Bengal, Howrah, wholesale fish market, 15.i.1982, P K Basak ex. baskets and gunny sacs containing fishes. 
Distribution: S. Europe, Africa and Oriental region as far as Japan and New Guinea. This species is fairly widely distributed in India.

Remark: They have been intercepted mainly from gunny sacs containing fishes.

\section{Philonthus gemellus Kraatz}

Philonthus gemellus Kraatz 1859, Arch. Naturg. 25: 91

Diagnosis: Body (Fig. 3) shining; head black, thorax, elytra and abdomen pitchy black; thorax with dorsal row of five rather large punctures; antennae black, first segment reddish yellow; legs reddish yellow, tibiae infuscate.

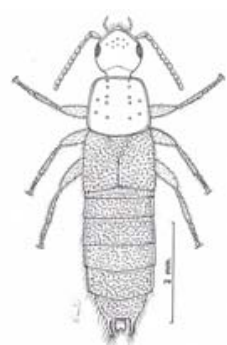

Fig.3. Philonthus gemellus Kraatz, Dorsal view.

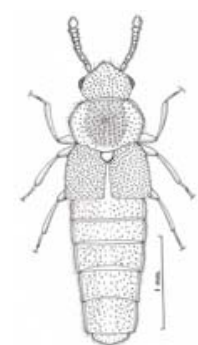

Fig.4, Coenonica puncticollis Kraatz, Dorsal view.

Length: 5.5-6.0 mm.

Material studied: 5ex; INDIA: W. Bengal, Howrah, wholesale fish market, 15.i.1982., P K Basak, ex. baskets and gunny sacs containing fishes.

Distribution: India, Sri Lanka, Malaysia and Indonesia (Java). From India, the species is hitherto known from Uttar Pradesh and presently from Kolkata: West Bengal.

Remark: There is no previous report of this species from the stored product habitat and they were collected from baskets and gunny sacs meant to carry fishes.

Subfamily: ALEOCHARINAE

Tribe: Bolitocharini

\section{Genus : Coenonica Kraatz}

Coenonica Kraatz 1857. Linn. Ent. 11 : 45.

Members of this genus are elongated in appearance; with more or less depressed and parallel or narrowed behind and somewhat convex; head narrower than thorax, constricted behind; thorax transverse, sides rounded in front, retracted and straighter behind with U- or V-shaped impression. Only one species, Coenonica puncticollis Kraatz has been collected in the present study.

\section{Coenonica puncticollis Kraatz}

Coenonica puncticollis Kraatz 1857. Linn. Ent. $11: 46$ 
Diagnosis: Body (Fig. 4) rather shining; head black, thorax and abdomen dark reddish-brown; elytra yellow, the scutellary region and postero-external angles black or infuscate; antenna pitchy, first three segments reddish-yellow; legs reddish yellow.

Length: 2.75-3 mm.

Material studied: 9 ex; INDIA: W. Bengal, Kolkata, Sovabazar, 19.iii.1982., P K Basak, ex. maize grain, 2 ex.; Kolkata, Posta, 24.iv 1985, P K Basak, ex. flour; 3ex.; Kolkata, Baghbazar, 7.xi.1984, P K Basak, ex. coir; 2 ex.; Kolkata, Chitpur, 23.vi. 1983, PK Basak ex. woodchips, 2ex.

Distribution: Widespread in the tropics. From India it is reported from West Bengal only.

Remarks: This species was recorded by Cameron (1939b) to infest sappy bark and decaying fruits. Aitken (1975) reported it from palm kernels and logs. In the present study it has been collected from maize grain, coir, wood chips and wheat flour.

Tribe: Aleocharini

Genus : Aleochara Grouvelle

Aleochara Grouvelle 1802. Col. Micr. Brunsw : 67.

This genus can be recognized by their rather convex, robust appearance that is narrower in front; thorax transverse, convex, the pronotal epipleura not visible from the side; sternites are not constricted; antenna somewhat stout. They are found mostly in carcasses, dung, decaying fungi, nests of burrowing mammals and other habitats. About 28 species are known from India (Cameron 1939b). Aitken (1975) recorded one species, Aleochara lanuginosa Gravenhorst from Europe, Mediterranean region and United States. In the present study, another species, A. puberula Klug is being recorded from stored products of India.

\section{Aleochara puberula Klug}

Aleochara puberula Klug 1832 - '33 Abh. Aka. Wiss. Berlin :139

Diagnosis: Body (Fig. 5) not very shining; head and abdomen black, the posterior margin of seventh and eighth segment of abdomen yellowish red; thorax reddish-brown, margins lighter; elytra red; antenna blackish, first three segments and apex of the last segment reddish-yellow.

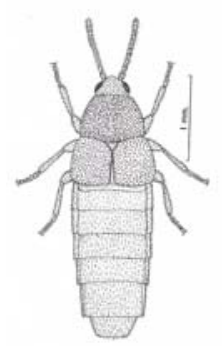

Fig.5. Aleochara puberula Klug, Dorsal view.

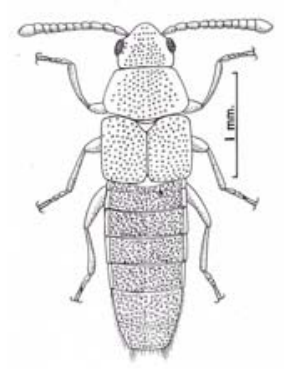

Fig.6. Oligota parva Kraatz, Dorsal view. 
Length: 3-4mm.

Material studied: 4exs. INDIA: W Bengal, Howrah, Wholesale fish market, 15.i.1982, P K Basak ex. Baskets and gunny sacs containing fishes.

Distribution: World-wide; fairly widely distributed in India.

Remark: This species was recorded by Cameron (1939b) to occur in dung and is presently intercepted from baskets and gunny sacs containing fishes.

Tribe Oligotini

\section{Genus : Oligota Mannerheim}

Oligota Mannerheim 1835, Mém. Ac. Sci. St. Petersb. $1: 72$

This is a small but widely distributed genus that includes 6 species from the Indian subcontinent of which two are only known from the Indian territory (Cameron 1939a). They are minute in size with 10-segmented clavate antenna, with head rounded behind, neck broad and inserted into thorax, pronotum short and broad with rounded sides, elytra not sinuate postero-externally, abdomen strongly bordered, legs with slender tibiae devoid of setae.

Aitken (1975) noted three species Oligota chrysopyga Kraatz, O. punctulata Heer and O. parva Kraatz from worldwide cargoes but none from India. Only the last mentioned species was found in the present study.

Oligota parva Kraatz

Oligota parva Kraatz 1862. Berl. Ent. 4: 300

Diagnosis: Body (Fig.6) narrow, sub-parallel, dark brown with elytra, legs and first four antennal segments yellowish brown.

Length: 3.2-3.5 mm.

Material studied: 12ex. INDIA: W. Bengal, Howrah, wholesale fish market, 15.i.1982 P K Basak, ex. baskets and gunny sacs containing fishes.

Distribution : Europe, Africa, Madeira, Cape Verde Islands, North America (Hinton 1945), and India : Kolkata (new record from the Indian subcontinent).

Remark: Woodroffe and Halstead (1959) recorded it in Brazil nuts; Aitken (1975) recorded it to infest wheat. In the present study it was collected in large numbers in baskets and gunny sacs used to carry fishes.

\section{Key to species of Staphylinidae from stored products of Kolkata}

1. Pronotum with dorsal row of 5 punctures and 3 others externally, head constricted behind and exserted ................................................. 2

- Pronotum with uniform or scattered punctures but not in rows; head unconstricted behind and not exserted .3

2. Frons of head sulcate; eyes distinctly shorter than temples; 1st segment of hind tarsi shorter than last segment . Philonthus gemellus Kraatz

- Frons of head smoothly rounded; eyes as long as or longer than temples; 1 stsegment of hind tarsi longer than last segment 
- Antenna 10-segmented

Oligota parva Kraatz

4. Lateral margins of pronotum nearly straight; eyes as long as temples; 1st segment of hind tarsi as long as last segment Philonthus paederoides Motschulsky

- Lateral margins of pronotum evenly curved, eyes longer than temples, $1^{\text {st }}$ segment of hind tarsi longer than last segment.

Philonthus minutus Bohemann

5. Pronotal epipleurea not visible from the side; elytra distinctly emarginated postero- externally Aleochara puberula Klug

- Pronotal epipleura visible from the side; elytra not emarginated postero- externally Coenonica puncticollis Kraatz

\section{Discussion}

The depredations of beetles in food stores were known to the people through ages. We find mention of damage of food stores, on the long voyage of the mariners, by the stored product beetles. A number of extensive works have been published afterwards on the stored product beetles, the more important amongst these include Lepesme (1944), Hinton (1945) and Aitken (1975). Representatives of at least 17 families have been among the beetle pests of stored products from different parts of the world. Of them, only Aitken (1975) had noted about 35 species of Staphylinidae from different commodities throughout the world. The development of beetle associates of stored food stuffs in the adaptive strategy and evolutionary course has been gradual. Crowson (1981) noted that human stores of food stuffs and other organic materials, constituting a 'special habitat', has been available only for a short time, probably for less than a million years in the evolutionary perspective.

Probably, all species of stored product beetles must be older than this habitat and could have moved to it from the primary natural habitats. Subcorticolous habitat of trees or decayed wood indeed is one of the most important habitat in which a number of beetles occurred, had moved secondarily to stored food stuff. Hinton (1943) pointed out that some of the stored product beetles appear to have been recruited from the species living in association with various vertebrates and invertebrates. Staphylinidae, one of the large families of beetles, have little diversity in mode of life. Majority of them are free living predators (Aleocharinae, Paederinae, Staphylininae) while some species become ecto-parasitic (several aleocharine species) on dipteran pupae or are myrmecophilous; some inhabit underside of bracket fungi (Tachyporinae) or are saprophagous (Ossorinae, Oxytelinae) or burrow in sands. The association of some species of Staphylinidae with stored food items poses interesting questions about their adaptations for exploitation of stored product habitats and life history strategies. It is almost obvious that the staphylinids are not directly involved in the destruction or depredation of food stuffs, but their presence in numbers in food stuff make it unsuitable for consumption. Facultatively predaceous habits have been well noted in several tenebrionids, lophocaterids and clerids etc. as well as cannibalism on each other's eggs and young is not atypical of various tenebrionids (Crowson 1981). The role of the staphylinids in stores is still very insufficiently known and deserves due attention of the storage entomologists. 


\section{Acknowledgements}

The authors are thankful to the Director, Zoological Survey of India, Kolkata for providing laboratory facilities. One of them (PKB) is grateful to the Principal as well as to Dr D Ray, Head of the Department of Zoology, Bidhannagar College for their support. They express their gratitude to $\operatorname{Dr} D$ G H Halstead, formerly of Slough Laboratory, $\mathrm{UK}$ for confirming the identifications and generous support in the study. We are grateful to the reviewer of the paper for critically going through it and to offer valuable suggestions for its improvement.

\section{References}

Aitken A D (1975) Insect Travellers, Vol. I. Coleoptera, Tech Bulletin 31 MAFF Publ. London 16: 1-191.

Cameron M (1930) The Fauna of British India including Ceylon and Burma. Coleoptera: Staphylinidae, Vol 1 (Micropeplinae, Oxytelinae, Oxyporinae, Steninae and Enaesthetinae); Taylor \& Francis, London.

Cameron M (1931a) The Fauna of British India including Ceylon and Burma.Coleoptera: Staphylinidae, Vol 2 (Paederinae); Taylor \& Francis, London.

Cameron M (1931b) The Fauna of British India including Ceylon and Burma.Coleoptera: Staphylinidae, Vol 4 Part II, Aleocharinae (Part);Taylor \& Francis, London.

Cameron M (1932) The Fauna of British India including Ceylon and Burma.Coleoptera: Staphylinidae, Vol 3 (Trichophyinae, Termidodiscinae, Pygosteninae and Tachyporinae );Taylor \& Francis, London.

Cameron M (1939a) The Fauna of British India including Ceylon and Burma.Coleoptera: Staphylinidae, Vol 4 Part I[Pseudoperenthinae and Aleocharine (Part)];Taylor \& Francis, London.

Cameron M (1939b) The Fauna of British India including Ceylon and Burma.Coleoptera: Staphylinidae, Vol. 4 Part II [Aleocharinae(Part)];Taylor \& Francis, London.

Crowson R A (1981) The biology of the Coleoptera. Academic Press, London.

Hinton H E (1943) Natural reservoirs of some beetles of the family Dermestidae known to infest stored products, with notes on those found in Spider's webs. Proc. R. ent. Soc. Lond. (A) 18:33-42.

Hinton H E (1945) A Monograph of the Beetles Associated with Stored Products, Vol I British Museum (Natural History), London.

Lawrence J F (1982) Coleoptera. pp.482-553. In: S P Parker (ed.) Synopsis and classification of Living Organisms Vol. 2. McGraw-Hill, New York.

Lepesme P (1944) Les Cole'opteres des denre'ss et des produits industriels entreposes. "Encyclopedie Entomologique" Vol. 22. Paris.

Pal T K (2003) Diversity of Indian beetle fauna (Coleoptera) : State of our knowledge and an estimation. In : R K Gupta (ed.) Advances in Insect Biodiversity; Agrobios (India), Jodhpur, pp.145-167.

Woodroffe G E and Halstead D G H (1959) Fulvinus brevicornis Reut (Hem., Miridae) and other insects breeding in stored brazil nuts in Britain. Entomologist's mon. Mag. 45: 130-133. 